\title{
Study of Missing Nutrient Technique on the Yield and Nutrient Uptake of Wheat
}

\author{
Ravi Kumar Meena ${ }^{1 *}$, Brijesh Yadav², Anil Kumar Verma², \\ Chiranjeev Kumawat ${ }^{2}$ and Abhishek Kumar ${ }^{1}$
}

\author{
${ }^{1}$ Department of Soil Science and Agricultural Chemistry, C. S. Azad University of Agriculture \\ and Technology, Kanpur-208002, India \\ ${ }^{2}$ ICAR-Indian Agriculture Research Institute, New Delhi-110012, India \\ *Corresponding author:
}

\begin{tabular}{|c|c|}
\hline & A B S T R A C T \\
\hline Keywords & \multirow{4}{*}{$\begin{array}{l}\text { Balanced fertilization is necessary for betterment of crop and soil health. To assess the } \\
\text { effect of different nutrient on yield uptake and soil fertility experiment was conducted in } \\
\text { pot culture in Department of Soil Science and Agricultural Chemistry, Chandra Shekhar } \\
\text { Azad University of Agriculture and Technology, Kanpur in 2012-13. Results revealed that } \\
\text { the omission of all studied nutrient (NPKSZnB) from complete treatment (NPKSZnB) } \\
\text { drastically decreased yield than continuously fertilized complete treatment. The amount of } \\
\text { yield increase obtained upon a missing element fertilization nearly equivalent to yield loss } \\
\text { when that particular nutrient was absent as compared to complete fertilization. When } \\
\text { nitrogen @120kg, phosphorus @ } 40 \mathrm{~kg} \text {, potassium @ } 40 \mathrm{~kg} \text {, zinc @ } 10 \mathrm{~kg} \text {, sulphur@ } 30 \\
\mathrm{~kg} \text { and boron @ } 1.0 \mathrm{~kg} \text { then results found not only highest grain and straw yield of wheat } \\
\text { but also better uptake of nutrient and render the soil in healthy and fertile condition as } \\
\text { compare to control or when any nutrient were missing. }\end{array}$} \\
\hline $\begin{array}{l}\text { Missing nutrient, } \\
\text { Uptake, } \\
\text { Nutrients, } \\
\text { Yield and balance } \\
\text { fertilization }\end{array}$ & \\
\hline Article Info & \\
\hline $\begin{array}{l}\text { Accepted: } \\
\text { 19 April } 2017 \\
\text { Available Online: } \\
10 \text { May } 2017\end{array}$ & \\
\hline
\end{tabular}

\section{Introduction}

Wheat (Triticum aestivum L.) is the first important and strategic cereal crop for the majority of world's populations. It contributes nearly one third of the total food grain production. Wheat is cultivated worldwide and most important staple food of about two billion people (36\% of world population). In 2008-09 world production of wheat was 645 million tonnes (DWR 2010); making it the third most produced cereal after maize (784 million tonnes) and rice (651 million tonnes). Wheat area has risen from 12.8 million hectare in 1966-67 to 29.8 million hectare in 2013-14. Wheat production in 2013-14 was
87 million tonnes (USDA, 2013-14) while the production of wheat crop in Uttar Pradesh was 30.3million tonnes from 9.74 million hectare area in 2012-13 (Ministry of Agriculture 2013). The area of wheat crop in Uttar Pradesh was increased up to 9.94 million hectare in 2013-14 (Economic Times 2014). The productivity of wheat in India in 2012-13 was $3119 \mathrm{Kgha}^{-1}$ and in Uttar Pradesh $3113 \mathrm{kgha}^{-1}$ (Ministry of Agriculture 2013). India is facing with an explosive population, hence a massive food production programme, specially for wheat is needed. India being the second largest in population, it 
is also the second largest in wheat consumption after China.

Soil is a biologically active layer of material resulting from complex transformations which in turn involve rock and mineral weathering, nutrient cycling, as well as biomass production and decomposition. It is thus the primary medium for plant growth (Novais et al., 2007). A way of maintaining nutrient levels and soil stability is to use fertilization. However, suitable management of fertilization involves defining not only the correct dosages and sources of nutrients but also the best seasons and methods to apply liming and fertilizers to the soil (Oliveira et al., 1991).The learning process of soil-plant relationships calls for experiments with which to identify nutrient deficiencies in the target species (Oliveira et al., 1991). The most widely used method in experiments on nutrient deficiency is the missing element technique, based on Liebig's law of the minimum (1840)

To increase the production of wheat in our country as well as state and to sustain the productivity of land proper management practices must be followed. To complete their life cycle plants need certain elements; which are known as essential nutrients and without them Plants are unable to complete their life cycle. These elements are carbon, oxygen, hydrogen, nitrogen, phosphorus, calcium, magnesium, sulphur, iron, manganese, zinc, copper, boron, molybdenum and chlorine. Out of these, carbon, oxygen and hydrogen are needed in highest amount and their source is atmosphere. In current study the N, P, K, S, $\mathrm{Zn}$ and $\mathrm{B}$ have been taken under missing nutrient technique on wheat crop.

\section{Materials and Methods}

The treatments details were as follows: $\mathbf{T}_{\mathbf{1}} ;$ Control, $\mathbf{T}_{\mathbf{2}} ; 120 \mathrm{~kg} \mathrm{~N}, \mathbf{T}_{\mathbf{3}} ; 120 \mathrm{~kg} \mathrm{~N}+40 \mathrm{~kg}$
$\mathrm{P}, \mathbf{T}_{\mathbf{4}} ; 120 \mathrm{~kg} \mathrm{~N}+40 \mathrm{~kg} \mathrm{P}+40 \mathrm{~kg} \mathrm{~K}, \mathbf{T}_{\mathbf{5}} ; 120$ $\mathrm{kg} \mathrm{N}+40 \mathrm{~kg} \mathrm{P}+40 \mathrm{~kg} \mathrm{~K}+10 \mathrm{~kg} \mathrm{ZnT_{6 }}$ $120 \mathrm{~kg} \mathrm{~N}+40 \mathrm{~kg} \mathrm{P}+40 \mathrm{~kg} \mathrm{~K}+30 \mathrm{~kg} \mathrm{~S}, \mathbf{T}_{7}$; $120 \mathrm{~kg} \mathrm{~N}+40 \mathrm{~kg} \mathrm{P}+40 \mathrm{~kg} \mathrm{~K}+10 \mathrm{~kg} \mathrm{Zn}+$ $30 \mathrm{~kg} \mathrm{~S}, \mathbf{T}_{\mathbf{8}} ; 120 \mathrm{~kg} \mathrm{~N}+40 \mathrm{~kg} \mathrm{P}+40 \mathrm{~kg} \mathrm{~K}+$ $10 \mathrm{~kg} \mathrm{Zn}+30 \mathrm{~kg} \mathrm{~S}+1.0 \mathrm{~kg} \mathrm{~B}$.

The experimental soils sandy loam in texture having $\mathrm{pH}(8.15)$, EC $\left(2.60 \mathrm{ds} \mathrm{m}^{-1}\right)$, organic carbon $\left(0.44 \mathrm{~g} \mathrm{~kg}^{-1}\right)$, available $\mathrm{N}\left(252 \mathrm{~kg} \mathrm{ha}^{-1}\right)$, available $\mathrm{P}_{2} \mathrm{O}_{5}\left(14.40 \mathrm{~kg} \mathrm{ha}^{-1}\right)$ available $\mathrm{K}$ (138 $\left.\mathrm{kg} \mathrm{ha}^{-1}\right)$, available $\mathrm{S}\left(9.80 \mathrm{~kg} \mathrm{ha}^{-1}\right)$, DTPA- extractable $\mathrm{Zn}(0.52 \mathrm{mg} \mathrm{kg}), \mathrm{Fe}$ (3.92 $\mathrm{mg} \mathrm{kg}^{-1}$ ), Mn (4.62 $\mathrm{mg} \mathrm{kg}^{-1}$ ) and $\mathrm{Cu}$ $\left(0.85 \mathrm{mg} \mathrm{kg}^{-1}\right)$ and available B $\left(0.47 \mathrm{mg} \mathrm{kg}^{-1}\right)$.

The post harvest soil samples were drawn from all the fields, and analyzed for $\mathrm{pH}$, electrical conductivity (Jackson, 1973), organic carbon (Walkley and Black, 1934). Soil samples were also analyzed for available nitrogen (Subbiah and Asija, 1956), available phosphorus (Olsen et al., 1954), available potassium (Hanway and Heidal, 1952) and $\mathrm{CaCl}_{2}$ extractable-S (Williams and Steinbergs, 1959). The available micronutrients ( $\mathrm{Zn}, \mathrm{Fe}$, $\mathrm{Cu}$ and $\mathrm{Mn}$ ) in soil were extracted by DTPA (Lindsay and Norvell, 1978) and determined on atomic absorption spectrophotometer. Hot water extractable boron was determined by colorimeter methods (Berger and Truog, 1939). The economics of various treatments was computed on the basis of prevailing market price of inputs and produces.

The experiment was conducted on cemented pots of $10 \mathrm{~kg}$ soil capacity in 'pot culture house' of the Department of Soil Science and Agricultural Chemistry, Chandra Shekhar Azad University of Agriculture and Technology, Kanpur during Rabi season 2012-13. It is located between latitude of $25^{0} 28^{\prime}$ to $26^{0} 58^{\prime}$ north and $79^{0} 31^{\prime}$ to $80^{0} 34^{\prime}$ east with an elevation of $125.9 \mathrm{~m}$ from the sea level. The pots $10 \mathrm{~kg}$ capacity having $30 \mathrm{~cm}$ diameter at the top and $26 \mathrm{~cm}$ depth were 
selected for the experiment. Each pot was filled with $10 \mathrm{~kg}$ well pulverized homogenous soil.

The formula expressed below was used for the computation of uptake of the nitrogen, phosphorus, potassium, sulphur, zinc and boron at harvest in both grains as well as straw.

Uptake of nutrient $\left(\mathrm{kgha}^{-1}\right)=$

Nutrient content (\%) X Yield $\left(\mathrm{kgha}^{-1}\right)$

\section{0}

The initial soil fertility status of soil use for filling the pots are shown in Table 1

The experiment was laid out in a complete randomized design with 8 treatments replicated with 4 times. The details of treatments given below:

The Seeds were sown on 26 Nov 2012 @ of $100 \mathrm{~kg} \mathrm{ha}^{-1}$. The half dose of the nitrogen and full dose of the phosphorus, potassium, sulphur, zinc and boron were applied before sowing i.e. basal dressing. The remaining amount of nitrogen was applied through top dressing after 22 to 25 days of date of sowing. The crop was harvested at maturity on $07 \mathrm{Apr}$ 2013 and bundles of each pot were tagged and kept separately. Harvested material of each pot were threshed and stored separately. Calculate the yield in $\mathrm{q} \mathrm{ha}^{-1}$. The data were subjected to statistical analysis by the method described by Chandel (1991).

\section{Results and Discussion}

The experimental results of grain and straw yield of wheat are presented in table 3. The grain yield varied from $31.00 \mathrm{qha}^{-1}$ to 48.20 qha $^{-1}$. The treatment $\mathrm{T}_{8}\left(\mathrm{~N}_{120}+\mathrm{P}_{40}+\mathrm{K}_{40}+\right.$ $\mathrm{Zn}_{10}+\mathrm{S}_{30}+\mathrm{B}_{1.0}$ ) gave the highest grain yield in present investigation. The experimental data clearly shows that all the treatments gave significantly higher grain yield in comparison to control. The grain yield of wheat increased by increasing the nutrient doses. The straw yield for different treatments ranged from 40.20 to $62.20 \mathrm{qha}^{-1}$. Highest straw yield $\left(62.20 \mathrm{qha}^{-1}\right)$ achieved from $\mathrm{T}_{8}\left(\mathrm{~N}_{120}+\mathrm{P}_{40}+\right.$ $\left.\mathrm{K}_{40}+\mathrm{Zn}_{10}+\mathrm{S}_{30}+\mathrm{B}_{1.0}\right)$. All the treatments gave significantly higher yield in comparison to control.Shah et al., (2008) also reported that the long-term missing of major nutrient individually from the complete treatment (NPKSZn) significantly decreased yield and still significantly higher than absolute control treatment. This may be due to Liebig's law of the minimum (1840) according to them, nutrient present in minimum amount, decide the growth of plants so until all the nutrient would not be present in optimum yield will also be sub optimum.

The data of table 3 shows the percent contribution of sequential addition of different nutrients under present study. The contribution of $\mathrm{N}$ over control was about 22.58 and $20.65 \%$ in grain and straw, respectively. Addition of $\mathrm{P}$ resulted in a positive interaction with $\mathrm{N}$ and magnitude of increase in yield over control reached up to 30.64 and $24.38 \%$ respectively in grain and straw. Addition of K and NP resulted in 43.87 and $37.31 \%$ Yield increase and addition of $\mathrm{S}$ to NPK gave almost similar increase in yield but when added $\mathrm{Zn}$ to NPKS, the magnitude of yield increase was 54.19 and $50 \%$ in grain and straw, respectively over control. Addition of boron to NPKS and $\mathrm{Zn}$ resulted highest increase in yield (55.48 and 55\%) in grain and straw respectively. The increased in grain yield of wheat from $\mathrm{T}_{1}$ to $\mathrm{T}_{8}$ is might be due to the increased availability of essential nutrients from the enhanced level of nutrients applied to the crop. These findings are in close conformity with the earlier findings of Parasuraman (2006) in maize. In this missing 
nutrient technique sufficient justification is exhibited in yield maximization through sequential missing nutrients. It was further observed that there have been responses of all the missing nutrients in varying degree.

The data pertaining to nutrient uptake are presented in table 4 and 5. Nutrient uptake was affected significantly due to various treatments. The uptake of $\mathrm{N}, \mathrm{P}, \mathrm{K}, \mathrm{S}, \mathrm{Zn}$ and $B$ by plants increased significantly with successive increase in nutrient level, which led to maximum N, P, K, S, Zn and B uptake. The data pertaining to nitrogen uptake are presented in table 4 . The nitrogen uptake in wheat grain ranged from 55.80 to $99.78 \mathrm{kgha}$ 1 . The treatment combination $\mathrm{T}_{8}\left(\mathrm{~N}_{120}+\mathrm{P}_{40}\right.$ $+\mathrm{K}_{40}+\mathrm{Zn}_{10}+\mathrm{S}_{30}+\mathrm{B}_{1.0} \mathrm{kgha}^{-1}$ ) gave the highest value of nitrogen uptake. The nitrogen uptake values in wheat straw ranged from 16.48 to $31.72 \mathrm{kgha}^{-1}$. Similar trends of variation were observed in this case. Total uptake was more or less similar to grain and straw uptake. The result of present investigation indicated that the increase in fertilizer dose gave the increasing values of all types of uptake. The phosphorus uptake varied from 9.61 to $18.80 \mathrm{kgha}^{-1}$ in wheat grain and 4.02 to $8.71 \mathrm{kgha}^{-1}$ in wheat straw. All the treatment combinations gave the higher uptake value in comparison to control. The total uptake values varied between 13.63 and $27.51 \mathrm{kgha}^{-1}$. All types of uptake values gave similar kind of variation. The uptake of potassium by the grain of wheat crop ranged from 6.20 to $12.05 \mathrm{~kg} \mathrm{ha}^{-1}$ and for the straw of wheat values varied from 70.35 to $130.62 \mathrm{~kg}$ $\mathrm{ha}^{-1}$.

The highest uptake of potassium for both grain and straw of wheat $12.05 \mathrm{~kg} \mathrm{ha}^{-1}$ and $130.62 \mathrm{~kg} \mathrm{ha}^{-1}$ were obtained from treatment combination $\mathrm{T}_{8}\left(\mathrm{~N}_{120}+\mathrm{P}_{40}+\mathrm{K}_{40}+\mathrm{Zn}_{10}+\mathrm{S}_{30}\right.$ $\left.+\mathrm{B}_{1.0} \mathrm{kgha}^{-1}\right)$. The total uptake of potassium varied from 76.55 to $142.67 \mathrm{~kg} \mathrm{ha}^{-1}$. The pattern of variation is more are less similar in all types of uptake values. The findings of Rana and Choudhary (2006) confirmed these results.

Table.1 Physic-chemical properties of pots soil before sowing and fertilization

\begin{tabular}{|c|c|c|}
\hline S.No. & Particulars & Values \\
\hline 1. & Sand $(\%)$ & 56.50 \\
\hline 2. & Silt $(\%)$ & 23.55 \\
\hline 3. & Clay $(\%)$ & 19.95 \\
\hline 4. & Textural Class & Loam \\
\hline 5. & $\mathrm{pH}(1: 2.5)$ & 8.15 \\
\hline 6. & $\mathrm{EC}(1: 2.5)\left(d \mathrm{Sm}^{-1}\right.$ at $\left.25^{-} \mathrm{C}\right)$ & 2.60 \\
\hline 7. & Organic Carbon $(\%)$ & 0.44 \\
\hline 8. & Available Nitrogen $\left(\mathrm{kg} \mathrm{ha}^{-1}\right)$ & 252.0 \\
\hline 9. & Available Phosphorus $\left(k g h a^{-1}\right)$ & 14.40 \\
\hline 10. & Available Potassium $\left(\mathrm{kg} \mathrm{ha}^{-1}\right)$ & 138.0 \\
\hline 11. & Available Sulphur $\left(\mathrm{kg} \mathrm{ha} a^{-1}\right)$ & 9.80 \\
\hline 12. & Available Zinc $(p p m)$ & 0.52 \\
\hline 13. & Available Boron (ppm) & 0.47 \\
\hline 14. & Particle Density $\left(\mathrm{mg} \mathrm{m}^{-3}\right)$ & 2.52 \\
\hline 15. & Bulk Density $\left(m g m^{-3}\right)$ & 1.34 \\
\hline 16. & Pore Space $(\%)$ & 45.0 \\
\hline
\end{tabular}


Table.2 Treatment Details

\begin{tabular}{ccl}
\hline S.No. & Treatment & Nutrient dose $\left(\mathbf{k g ~ h a}^{-1}\right)$ \\
\hline $\mathbf{1 .}$ & $\mathrm{T}_{1}$ & Control \\
$\mathbf{2 .}$ & $\mathrm{T}_{2}$ & $120 \mathrm{~kg} \mathrm{~N}$ \\
$\mathbf{3 .}$ & $\mathrm{T}_{3}$ & $120 \mathrm{~kg} \mathrm{~N}+40 \mathrm{~kg} \mathrm{P}$ \\
$\mathbf{4 .}$ & $\mathrm{T}_{4}$ & $120 \mathrm{~kg} \mathrm{~N}+40 \mathrm{~kg} \mathrm{P}+40 \mathrm{~kg} \mathrm{~K}$ \\
$\mathbf{5 .}$ & $\mathrm{T}_{5}$ & $120 \mathrm{~kg} \mathrm{~N}+40 \mathrm{~kg} \mathrm{P}+40 \mathrm{~kg} \mathrm{~K}+10 \mathrm{~kg} \mathrm{Zn}$ \\
$\mathbf{6 .}$ & $\mathrm{T}_{6}$ & $120 \mathrm{~kg} \mathrm{~N}+40 \mathrm{~kg} \mathrm{P}+40 \mathrm{~kg} \mathrm{~K}+30 \mathrm{~kg} \mathrm{~S}$ \\
$\mathbf{7 .}$ & $\mathrm{T}_{7}$ & $120 \mathrm{~kg} \mathrm{~N}+40 \mathrm{~kg} \mathrm{P}+40 \mathrm{~kg} \mathrm{~K}+10 \mathrm{~kg} \mathrm{Zn}+30 \mathrm{~kg} \mathrm{~S}$ \\
$\mathbf{8 .}$ & $\mathrm{T}_{8}$ & $120 \mathrm{~kg} \mathrm{~N}+40 \mathrm{~kg} \mathrm{P}+40 \mathrm{~kg} \mathrm{~K}+10 \mathrm{~kg} \mathrm{Zn}+30 \mathrm{~kg} \mathrm{~S}+1.0 \mathrm{~kg} \mathrm{~B}$ \\
\hline
\end{tabular}

Table.3 Effect of different treatments on grain and straw yields of wheat crop (qha-1)

\begin{tabular}{|c|c|c|c|c|c|}
\hline \multirow{2}{*}{$\begin{array}{c}\text { Treatment } \\
\text { no. }\end{array}$} & \multirow{2}{*}{ Treatments details } & \multicolumn{2}{|c|}{ Average yield $\left(\mathrm{qha}^{-1}\right)$} & \multicolumn{2}{|c|}{$\begin{array}{r}\text { Percent increase } \\
\text { over control }\end{array}$} \\
\hline & & Grain & Straw & Grain & Straw \\
\hline $\mathbf{T}_{1}$ & Control & 31.00 & 40.20 & - & - \\
\hline $\mathbf{T}_{2}$ & $\mathrm{~N}_{120}$ & 38.00 & 48.50 & 22.58 & 20.65 \\
\hline $\mathbf{T}_{\mathbf{3}}$ & $\mathrm{N}_{120}+\mathrm{P}_{40}$ & 40.50 & 50.00 & 30.64 & 24.38 \\
\hline $\mathbf{T}_{4}$ & $\mathrm{~N}_{120}+\mathrm{P}_{40}+\mathrm{K}_{40}$ & 44.60 & 55.20 & 43.87 & 37.31 \\
\hline $\mathbf{T}_{5}$ & $\mathrm{~N}_{120}+\mathrm{P}_{40}+\mathrm{K}_{40}+\mathrm{Zn}_{10}$ & 45.80 & 56.10 & 47.74 & 39.55 \\
\hline $\mathbf{T}_{6}$ & $\mathrm{~N}_{120}+\mathrm{P}_{40}+\mathrm{K}_{40}+\mathrm{S}_{30}$ & 46.70 & 58.00 & 50.64 & 44.28 \\
\hline $\mathbf{T}_{7}$ & $\mathrm{~N}_{120}+\mathrm{P}_{40}+\mathrm{K}_{40}+\mathrm{Zn}_{10}+\mathrm{S}_{30}$ & 47.80 & 60.00 & 54.19 & 49.25 \\
\hline \multirow[t]{3}{*}{$\mathbf{T}_{8}$} & $\mathrm{~N}_{120}+\mathrm{P}_{40}+\mathrm{K}_{40}+\mathrm{Zn}_{10}+\mathrm{S}_{30}+\mathrm{B}_{1.0}$ & 48.20 & 62.20 & 55.48 & 54.73 \\
\hline & S.E. \pm & 0.4636 & 0.5304 & & \\
\hline & C.D. (at $\overline{5} \%)$ & 1.3533 & 1.5481 & & \\
\hline
\end{tabular}

Table.4 Effect of different treatments on the uptake of Nitrogen, Phosphorus and potassium on wheat crop (kgha-1)

\begin{tabular}{|c|c|c|c|c|c|c|c|c|c|}
\hline \multirow[t]{3}{*}{ Treatment } & \multicolumn{9}{|c|}{ Nutrient uptake $\mathrm{Kg} \mathrm{ha}^{-1}$} \\
\hline & \multicolumn{3}{|c|}{$\mathbf{N}$} & \multicolumn{3}{|c|}{$\mathbf{P}$} & \multicolumn{3}{|c|}{$\mathbf{K}$} \\
\hline & Grain & Straw & Total & Grain & Straw & Total) & Grain & Straw & Total \\
\hline $\mathbf{T}_{1}$ & 55.80 & 16.48 & 72.28 & 9.61 & 4.02 & 13.63 & 6.20 & 70.35 & 76.55 \\
\hline $\mathbf{T}_{2}$ & 71.44 & 20.86 & 92.29 & 12.16 & 5.34 & 17.50 & 7.98 & 89.73 & 97.71 \\
\hline $\mathbf{T}_{3}$ & 79.38 & 22.50 & 101.88 & 13.77 & 6.00 & 19.77 & 8.91 & 93.50 & 102.41 \\
\hline $\mathbf{T}_{4}$ & 86.53 & 25.39 & 111.92 & 15.61 & 7.18 & 22.79 & 10.26 & 104.88 & 115.14 \\
\hline $\mathbf{T}_{5}$ & 90.23 & 26.36 & $116 . .59$ & 16.49 & 6.73 & 23.22 & 10.08 & 107.71 & 117.79 \\
\hline $\mathbf{T}_{6}$ & 92.47 & 27.84 & 120.31 & 17.28 & 7.54 & 24.82 & 10.74 & 112.52 & 123.26 \\
\hline $\mathbf{T}_{7}$ & 95.60 & 29.40 & 125.00 & 18.16 & 7.80 & 25.96 & 11.47 & 117.60 & 129.08 \\
\hline $\mathbf{T}_{8}$ & 99.78 & 31.72 & 131.49 & 18.80 & 8.71 & 27.51 & 12.05 & 130.62 & 142.67 \\
\hline S.E. \pm & 2.2421 & 1.6031 & & 1.2096 & 0.3758 & & 0.4467 & 0.5025 & - \\
\hline $\mathrm{CD}$ at $\overline{\mathbf{5}} \%$ & 6.5443 & 4.6789 & - & 3.5306 & 1.0969 & - & 1.3039 & 1.4667 & - \\
\hline
\end{tabular}


Table.5 Effect of different treatments on the uptake of sulphur,zinc and boron on wheat crop (kgha-1)

\begin{tabular}{|c|c|c|c|c|c|c|c|c|c|}
\hline \multirow[t]{3}{*}{ Treatment } & \multicolumn{9}{|c|}{ Nutrient uptake $\mathrm{Kg} \mathrm{ha}^{-1}$} \\
\hline & \multicolumn{3}{|c|}{$\mathbf{S}$} & \multicolumn{3}{|c|}{ Zn } & \multicolumn{3}{|c|}{$\mathbf{B}$} \\
\hline & Grain & Straw & Total & Grain & Straw & Total & Grain & Straw & Total \\
\hline $\mathbf{T}_{1}$ & 3.41 & 4.42 & 7.83 & 46.50 & 44.22 & 90.72 & 62.00 & 52.26 & 114.26 \\
\hline $\mathbf{T}_{2}$ & 4.94 & 5.82 & 10.76 & 60.80 & 63.05 & 123.85 & 83.60 & 72.75 & 156.35 \\
\hline $\mathbf{T}_{3}$ & 5.67 & 6.50 & 12.17 & 72.90 & 70.00 & 142.90 & 93.15 & 80.00 & 173.15 \\
\hline $\mathbf{T}_{4}$ & 6.69 & 7.72 & 14.41 & 89.20 & 81.69 & $170 . .89$ & 115.96 & 94.94 & 210.90 \\
\hline $\mathbf{T}_{5}$ & 7.33 & 7.85 & 15.18 & 100.76 & 85.27 & 186.03 & 128.24 & 103.22 & 231.46 \\
\hline $\mathbf{T}_{6}$ & 8.41 & 8.70 & 17.11 & 107.41 & 90.48 & 199.89 & 126.09 & 101.50 & 227.59 \\
\hline $\mathbf{T}_{7}$ & 9.08 & 9.60 & 18.68 & 114.72 & 100.80 & 215.52 & 138.62 & 114.00 & 252.62 \\
\hline $\mathbf{T}_{8}$ & 9.64 & 10.58 & 20.21 & 119.54 & 119.96 & 231.49 & 149.42 & 130.62 & 280.04 \\
\hline S.E. \pm & 0.3550 & 0.2993 & & 0.8058 & 0.5556 & & 0.6072 & 0.6675 & \\
\hline CD at $5 \%$ & 1.0362 & 0.8736 & & 2.3518 & 1.6218 & & 1.7724 & 1.9484 & \\
\hline
\end{tabular}

Table.6 Effect of different treatments on the nutrients content in soil after harvest of wheat crop

\begin{tabular}{cccccccc}
\hline $\begin{array}{c}\text { Treatment } \\
\text { No. }\end{array}$ & $\begin{array}{c}\text { O.C. } \\
(\mathbf{\%})\end{array}$ & $\begin{array}{c}\mathbf{N} \\
\left(\mathbf{K g h a}^{-\mathbf{1}}\right)\end{array}$ & $\begin{array}{c}\mathbf{P} \\
\left(\mathbf{k g h a}^{-\mathbf{1}}\right)\end{array}$ & $\begin{array}{c}\mathbf{K} \\
\left(\mathbf{k g h a}^{-\mathbf{1}}\right)\end{array}$ & $\begin{array}{c}\mathbf{S} \\
\left(\mathbf{k g h a}^{-\mathbf{1}}\right)\end{array}$ & $\begin{array}{c}\mathbf{Z n} \\
(\mathbf{p p m})\end{array}$ & $\begin{array}{c}\mathbf{B} \\
(\mathbf{p p m})\end{array}$ \\
\hline $\mathbf{T}_{\mathbf{1}}$ & 0.46 & 252 & 13.7 & 139.4 & 9.60 & 0.52 & 0.42 \\
$\mathbf{T}_{\mathbf{2}}$ & 0.47 & 257 & 13.9 & 139.6 & 9.61 & 0.53 & 0.43 \\
$\mathbf{T}_{\mathbf{3}}$ & 0.47 & 258 & 14.1 & 139.5 & 9.62 & 0.54 & 0.44 \\
$\mathbf{T}_{\mathbf{4}}$ & 0.48 & 260 & 14.2 & 140.0 & 9.63 & 0.55 & 0.47 \\
$\mathbf{T}_{\mathbf{5}}$ & 0.48 & 262 & 14.3 & 140.2 & 9.64 & 0.57 & 0.47 \\
$\mathbf{T}_{\mathbf{6}}$ & 0.48 & 262 & 14.4 & 140.3 & 9.74 & 0.56 & 0.46 \\
$\mathbf{T}_{\mathbf{7}}$ & 0.48 & 263 & 14.5 & 140.5 & 9.80 & 0.60 & 0.47 \\
$\mathbf{T}_{\mathbf{8}}$ & 0.48 & 264 & 14.6 & 140.9 & 9.80 & 0.60 & 0.50 \\
\hline
\end{tabular}

The result of present investigation related to uptake of sulphur, zinc and boron are presented in table 5. The uptake values of sulphur in grain ranged from 3.41 to $9.64 \mathrm{~kg}$ $\mathrm{ha}^{-1}$. The uptake values in straw ranged from 4.42 to $10.58 \mathrm{~kg} \mathrm{ha}^{-1}$ while the total uptake values varied from 7.83 to $20.21 \mathrm{~kg} \mathrm{ha}^{-1}$. The treatment combination $\mathrm{T}_{8}\left(\mathrm{~N}_{120}+\mathrm{P}_{40}+\mathrm{K}_{40}+\right.$ $\mathrm{Zn}_{10}+\mathrm{S}_{30}+\mathrm{B}_{1.0} \mathrm{kgha}^{-1}$ ) gave the highest values of grain, straw and total uptake in this case also. The sulphur uptake values increased when supply of fertilizers increased. The zinc and boron uptake values in grain and straw also follow similar trend. Uptake of zinc in grain and straw varied from 46.50 to $119.54 \mathrm{~g} \mathrm{ha}^{-1}$ and 44.22 to $119.96 \mathrm{~g} \mathrm{ha}^{-1}$ respectively. The total uptake values varied from 90.72 to $231.49 \mathrm{~g} \mathrm{ha}^{-1}$. The values are more or less similar to other nutrient content. The treatment $\mathrm{T}_{8}\left(\mathrm{~N}_{120}+\mathrm{P}_{40}+\mathrm{K}_{40}+\mathrm{Zn}_{10}+\right.$ $\mathrm{S}_{30}+\mathrm{B}_{1.0} \mathrm{~kg} \mathrm{ha}^{-1}$ ) once again was found best combination of fertilizers. It is in accordance with the finding of Kedar Prasad et al., (2005) which told that due to the balanced supply of all nutrients to plants at all stages of crop growth. The grain and straw uptake values of boron in wheat crop varied from 62.00 to $149.42 \mathrm{~g} \mathrm{ha}^{-1}$ and 52.26 to $130.62 \mathrm{~g} \mathrm{ha}^{-1}$ respectively. The total uptake value varied from 114.26 to $280.04 \mathrm{~g} \mathrm{ha}^{-1}$. The result is more or less similar to other nutrient content. The treatment $\mathrm{T}_{8}\left(\mathrm{~N}_{120}+\mathrm{P}_{40}+\mathrm{K}_{40}+\mathrm{Zn}_{10}+\right.$ $\mathrm{S}_{30}+\mathrm{B}_{1.0} \mathrm{~kg} \mathrm{ha}{ }^{-1}$ ) once again was found superior over other treatments. It is also 
important that nutrient minus treatments gave the lower nutrient uptake in comparison to nutrient containing combinations. Similar result found by paramasivan et al., (2012) showed that the lower uptake of N, P, K and $\mathrm{Zn}$ was in treatments omitted with $\mathrm{N}, \mathrm{P}$ or K and in absolute control.

Effect of different treatments on soil fertility status is revealed in table 7. Data are showing that after harvesting organic carbon, available $\mathrm{N}, \mathrm{P}, \mathrm{K}, \mathrm{S}, \mathrm{Zn}$ and $\mathrm{B}$ content are found highest in soil having treatment $\mathrm{T}_{8}$ while minimum in $\mathrm{T}_{1}$ or control. The better build up of soil fertility in treatment $T_{8}$ is due to balanced fertilization. Balanced fertilization not only increase yield and uptake of particular nutrient but also render the soil in healthy and well fertile condition which make the basis for sustainable crop management. These results are in agreement with the findings of Brar et al., (2006).

\section{References}

Brar, B.S., Dhillon, N.S., Benipal, D.S., Jagadeep Singh and Mavi, M.S. 2006. Balanced use of inorganic fertilizers and FYM for higher crop yields and better soil health in maize - wheat cropping system. J. Res., Punjab Agric. Univ., 43(2): 104-107.

Chandel, S.R.S. 1991. A handbook of Agricultural Statistics, 8th Ed, 1991.

Chesnin, L. and Yien, C.H. 1950. Turbidimetric determination of available sulphates. Soil Sci. Society American Proceeding, 15: 149-151.

Hanway, J.J and Heidel, H. 1952. soil analysis methods as used in Iowa State College, Soil Testing Laboratory, Iowa State College Bull., 57: 1-131.

Harp, D.L. 1997. Modifications to the azomethine-H method for determining boron in water. Anal. Chim. Acta., 346: 373. http://articles.economictimes.indiatimes .com/2014-0113/news/46149797_1_wheatproduction-wheat-acreage-main-rabi Jackson, M.L. 1973. Soil Chemical Analysis, Prentice Hall of India Private Limited, New Delhi, pp.

Kedar Prasad, Verma, C.P., Verma, R.N. and Ram Pyare. 2005. Effect of FYM, gypsum and fertility levels on nutrient uptake by wheat crop in maize - wheat system. Crop Res., 29(1): 28-33.

Liebig, J. 1840. Die organische Chemie in ihrer Anwendung auf Agri Sprengel, C. 1831. Chemiefu " $\mathrm{r}$ Land wirthe, Forstma "nnerund Cameraliscultur und Physiologie (Organic chemistry in its applications to agri- ten (Chemistry for agronomists, foresters, and agricultural econoculture and physiology). Friedrich Vieweg und Sohn Publ. Co., mists). Volume 1. Vandenhoeck und Ruprecht Publ. Co., Go“t Braunschweig, Germany.

Novais, R.F., Alvarez, V.H.V., Barros, N.F., Fontes, R.L.F., CAntarutti, R.B., Neves, J.C.L. Fertilidade do solo. Viçosa, MG: SBCS, 1017 p.

Oliveira, A.J., Garrido, W.E., Araújo, J.D., LOurenço, S. (Coord.). Métodos de pesquisa em fertilidade do solo. Brasília: EMBRAPA-SEA, 392 p.

Olsen, S.R., Cole C.V., Watanabe, F.S. and Dean, L.A. 1954. Estimation of Available phosphorus in soils by extraction with sodium bicarbonate USDA Cir.939 USDA, Washington DC.

Paramasivan, M., Malarvizhi, P. and Thiyageswar, S. 2012. Balanced use of inorganic fertilizers on maize (Zea mays) yield, nutrient uptake and soil fertility in alfisols. Karnataka J. Agric. Sci., 25(4): 423-426.

Parasuraman, P. 2006. Studies on nutrient requirement of hybrid maize (Zea mays L.) under irrigated conditions. Mysore J. 
Agric., Sci., 40(1): 14-20.

Piper, C.S. 1966. Soil and Plant Analysis Hans Publications, Bombay.

Rana, K.S. and Choudhary, R.S. 2006. Productivity, nitrogen uptake and water use in maize (Zea mays L.) mungbean intercropping system as affected by nitrogen levels under rainfed conditions. Crop Res., 32(3): 306-308.

Shah, A.L., Islam, M.R., Haque, M.M., Ishaque, M. and Miah M.A.M. 2008. Efficacy of major nutrients in rice production. Bangladesh. J. Agril. Res., 33(3): 639-645.

State of Indian Agriculture. 2012-13. Ministry of Agriculture Department of Agriculture and Cooperation
Directorate of Economics and Statistics New Delhi

Subbiah, B.V., Asija, G.L. 1956. A rapid procedure for estimation of available nitrogen in soils. Curr. Sci., 25: 259260.

USDA.

2013-14

http://www.thehindubusinessline.com/e conomy/agri-business/usda-sees-indias201314-wheat-crop-lower-than-govtestimate/article4807318.ece

Walkley, A., Black, I.A. 1934. An examination of Degtjareff method for determining soil organic matter, and proposed modification of the chromic acid titration method. Soil Sci., 37: 2938.

\section{How to cite this article:}

Ravi Kumar Meena, Brijesh Yadav, Anil Kumar Verma, Chiranjeev Kumawat, Abhishek Kumar. 2017. Study of Missing Nutrient Technique on the Yield and Nutrient Uptake of Wheat. Int.J.Curr.Microbiol.App.Sci. 6(5): 2026-2033. doi: https://doi.org/10.20546/ijcmas.2017.605.226 